野口雅之 $^{1}$

要旨一一肺末梢に発生する腺癌の多くは肺胞上皮置換性に増殖する細気管支肺胞上皮癌（bronchioloalveolar carcinoma，BAC)を介して浸潤癌に進展すると考えられる. BAC を含む小型肺腺癌を病理形態学的に分類する場合, 置換 性増殖群と非置換性増殖群に分けるのが合理的である．後者はどんなに小さくとも浸潤癌であるが，前者のうち BAC は上皮内癌で予後が良いが, これに線維芽細胞の増殖巣が加わると予後が悪くなることがわかっている.この点につい ての研究は多数報告がある.たとえば形態学的検討では腫瘍内の線維化部分における線維芽細胞の増生巣の割合は予 後と良く相関する。分子病理学的には BAC では特徵的に Bax inhibitor-1 の発現が高く, epidermal growth factor receptor (EGFR) の変異率も高いが逆にp16 遺伝子のプロモーター領域の過剰メチル化は認めない. これらの違いは BAC を構成する腫瘍細胞が浸潤癌のそれと明らかに性質の異なる腫瘍細胞であることを示している.（肺癌. 2007;47: 921-925)

索引用語 一一肺腺癌, 野口分類, 予後, OCIAD2

\title{
Histogenesis and Biology of Adenocarcinoma of the Lung
}

\author{
Masayuki Noguchi ${ }^{1}$
}

\begin{abstract}
Adenocarcinomas developed in peripheral lung generally progress to invasive carcinoma through bronchioloalveolar carcinoma (BAC). When classifying small sized lung adenocarcinomas that include a BAC component pathologically, it is reasonable to divide them into two groups: replacement type and non-replacement type. Although the latter is invasive regardless of its size, the former group that includes a BAC component, particularly pureBAC which is in situ carcinoma, shows an extremely favorable prognosis, although the prognosis becomes worse as fibroblast proliferation progresses. Many studies have examined the relationship between fibrosis or fibroblast proliferation and outcome, and morphologically, ratio between areas of fibrosis and fibroblast proliferation is known to affect outcome. Molecular biological studies have shown that BAC has a characteristically high rate of Bax inhibitor-1 expression and frequent mutation of epidermal growth factor receptor (EGFR) gene, but BAC does not show hypermethylation of p16 gene. These differences between BAC and non-BAC indicate that the character of BAC clearly differs from that of invasive adenocarcinoma (non-BAC).(JJLC. 2007;47:921-925)
\end{abstract}

KEY WORDS — Lung adenocarcinoma, Noguchi’s classification, Prognosis, OCIAD2

\section{はじめに}

2004 年に一部修正された WHO 分類によれば, 肺腺癌 は基本的に腺管型, 乳頭型, 細気管支肺胞上皮型 (bronchioloalveolar carcinoma, BAC), 充実粘液産生型, 混合 型の 5 種類に分類されているが，この中で BAC は既存
の肺胞上皮を置換性に増殖する腺癌で, 間質浸潤, 脈管 浸潤, 胸膜浸潤を認めない腫瘍で極めて予後が良いと書 かれている（Table 1).1 つまり BACは上皮内癌といえ る. 一方 BAC と同様に既存の肺胞上皮を置換しながら 増殖する腫瘍性病変として, 異型腺腫様過形成 (atypical adenomatous hyperplasia, AAH）という前浸潤病変も
1筑波大学大学院人間総合科学研究科.

1University of Tsukuba Graduate School of Comprehensive Hu- man Sciences, Japan.

(C) 2007 The Japan Lung Cancer Society 
Table 1. WHO Classification of Adenocarcinoma

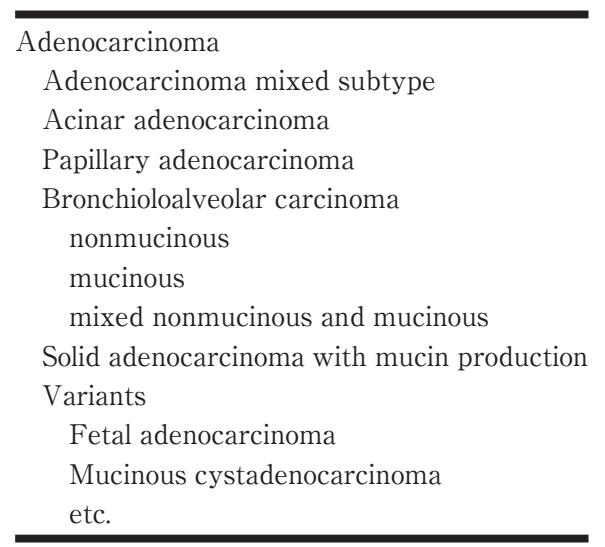

WHO Classification Tumours of the Lung, Pleura, Thymus and Heart, IARC Press, Lyon, 2004. IARC (International Agency for Research on Cancer).
Table 2. Histological Classification of Small Adenocarcinoma

Replacement Type Adenocarcinoma

A: Localized bronchioloalveolar carcinoma (LBAC)

B: LBAC with foci of collapse of alveolar structure

C: LBAC with foci of active fibroblastic proliferation

Non-replacement Type Adenocarcinoma

D: Poorly differentiated adenocarcinoma

E: Tubular adenocarcinoma

F: Papillary adenocarcinoma with compressive and destructive growth

Noguchi M. et al. Cancer 75:2844-2852, 1995

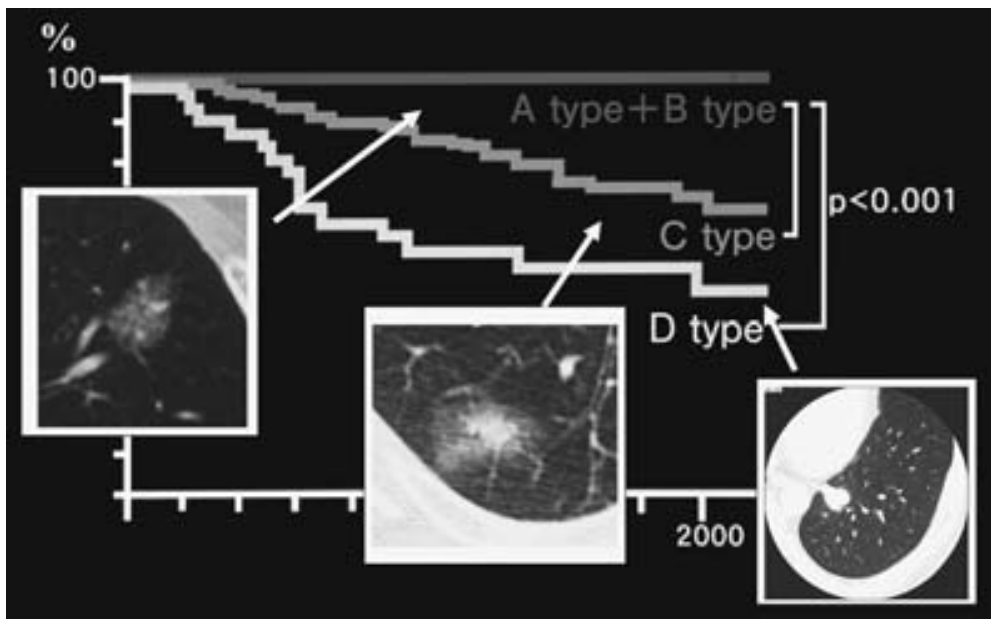

Figure 1.

WHO では定義している. AAH は大方径 $5 \mathrm{~mm}$ と小型で 肺腺癌の前癌病変と考えられているが, その増殖様式は 前述の BAC と同様である. 従って $\mathrm{BAC}$ とAH の鑑別 は構造上は不可能であるが, 個々の腫瘍細胞の核異型な どで鑑別されている。しかし BACも AAHも非浸潤性 病変なので切除されれば極めて予後が良く, 生物学的に は分類する必要のないものである。このように肺腺癌の 中には極めて予後の良い種類が混在している. BACも $\mathrm{AAH}$ もその多くは小型な病変で, $\mathrm{CT}$ 検診を行うことに よってその発見頻度は加速度的に増加してきた。このよ うな小型腺癌の発生要因と生物学について最近の知見を のべる.

\section{野口分類}

小型の肺腺癌を合理的に分類するにはその構造所見を 主に考えて分類すると都合が良い。つまりはじめに，既 存の肺胞上皮を置換しながら増殖するグループと破壊し ながら増殖するグループの 2 つに分ける，置換性増殖す るグループは線維化のないいわゆる限局性の細気管支肺 胞上皮癌 (localized bronchioloalveolar carcinoma, LBAC) (タイプ A) と LBAC に肺胞の虚脱が加わったタ イプ (タイプ B), さらに LBAC に線維芽細胞の増生巣の 加わったタイプ (タイプC)に分類される. 非置換性増殖 するグループはいわゆる低分化腺癌 (タイプ D), 管状腺 癌 (タイプ E), 乳頭状腺癌 (タイプ F) に分類される 


\section{Fibroblastic proliferation/fibrosis area ratio for type $\mathbf{C}$ adenocarcinoma}

A

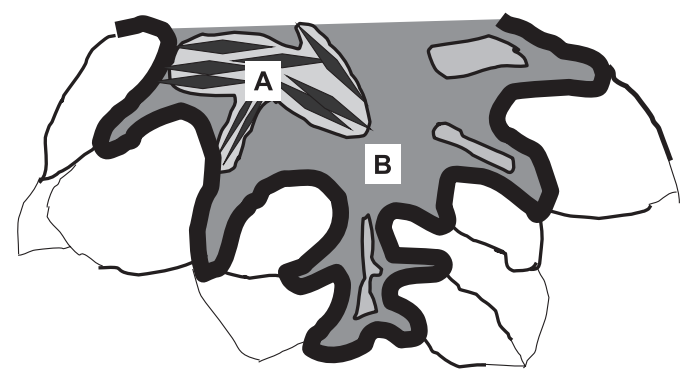

A: Area of fibroblastic proliferation B: Fibrotic area

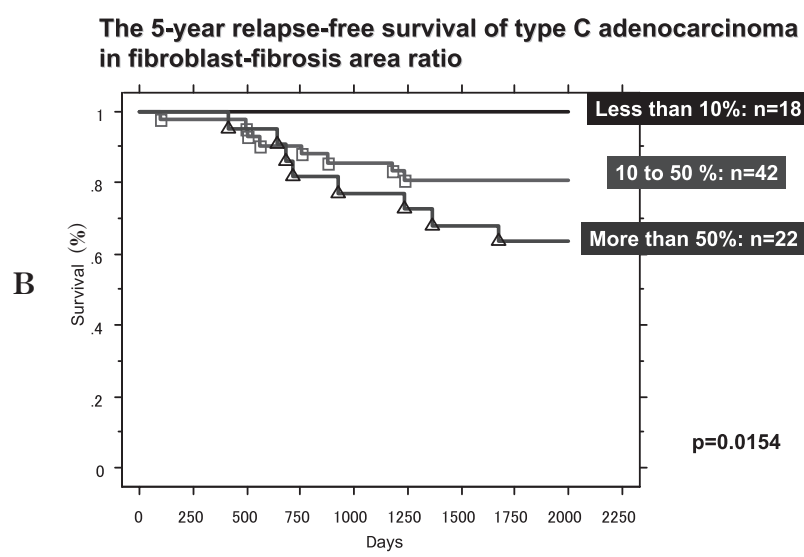

Minami Y. et al. Lung Cancer 48:339, 2005

Figure 2.

(Table 2). ${ }^{2}$ このような小型肺腺癌分類を一般的に『野 口分類』と呼んでいる.この分類の利点は 2 つに集約さ れる. 1 つはこの分類は腺癌の予後と極めて良く相関す ることにある. Figure 1 に示すようにタイプ A，Bの腫 瘍は極めて予後が良く， 5 年生存率が $100 \%$ で生物学的 にはこれらの腫瘍は上皮内腫瘍といえる。またタイプ $\mathrm{A}, \mathrm{B}$ と同様に置換性增殖するグループのタイプ C は夕 イプ A, B より予後が悪く, 5 年生存率が $75 \%$ 程度に低 下する．さらに非置換性増殖グループの中で最も頻度の 高いタイプ D では直径 $2 \mathrm{~cm}$ 以下の小型腺癌であっても その 5 年生存率は高々 $50 \%$ 程度しかないことがわかる.

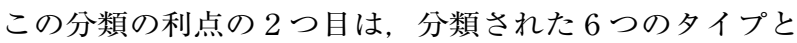
CT 所見が極めて良く相関することにある。非置換性の グループの 3 つタイプはすべて高吸収域よりなる solid な所見を示すが, 置換性のグループの 3 つのタイプ はいわゆるすりガラス状陰影 (ground glass opacity, GGO）という所見を呈する。 またタイプ A は多くの場合 すべてがこの GGO の所見を呈し CT 所見としては pure GGO と呼ばれる。またタイプ Cでは一部が GGO で一部
が solid な場合が多く, mixed GGO と呼ばれることにな る (Figure 1)。つまり CT 所見からその組織構築が想像 でき, 組織構築を基盤とした野口分類と対応が可能で, さらにはその予後が正確に推定できることになる。この 際非置換性増殖をする 3 タイプはすべて浸潤癌で小型と いっても予後が悪い集団であるから，発見した場合はス タンダードな肺葉切除の適応になるのは勿論であるが, 置換性増殖をするタイプ A， B は上皮内腫瘍でもあり， 積極的縮小手術の対象になる. 一方タイプC は予後の良 い腫瘍と悪い腫瘍が混在していることになる.

最近 CTを用いた肺癌検診が盛んに行われるように なってきている．たとえば茨城県日立市の CT 検診では 初回検診で 1998〜2003 年の間に 13,536 名の検診を行っ ているが，そのうち 927 名 $(6.8 \%)$ が要精検で，そのう ち 60 名の肺癌が発見されている。肺癌発見率は $0.443 \%$ で極めて高い数字である.また発見された肺癌の $90 \%$ は I 期肺癌でそれも $83 \%$ は IA 期の肺癌であった。発見さ れた肺癌の CT 所見に注目するとその約 4 分の 1 はいわ ゆる pure GGO であり,ささらに 4 分の 1 は solid なタイプ であった．つまり前者は積極的縮小手術の対象となり， 後者は小型であっても縦隔リンパ郭清を含む肺葉切除が 必要な集団である。一方残りの 2 分の 1 は mixed GGO の症例であった，つまり今後もさらに拡大して行われる であろう CT 検診で見つかってくる腫瘍の半分は mixed GGO と呼ばれる予後の良い,つまり縮小手術をすべき症 例と予後の悪いスタンダードな肺葉切除を必要とする症 例の混在したタイプであることが想像される.

\section{小型腺癌の予後因子の探索}

野口分類の項で示したように CT 検診で見つかる多く の mixed GGO の症例は, 組織学的にタイプ C と診断さ れる。このタイプCは予後の良い腺癌と悪い腺癌の混在 したタイプであるのでこのタイプCをさらに予後良性 群と不良群に分類する試みがなされている。 その 1 つを 紹介すると, Minami らによれば線維化巣の中に占める 線維芽細胞の増生巣の割合 (area of fibroblastic proliferation/fibrosis，F/F ratio）を用いると，この割合が $10 \%$ 未満のタイプ C の症例には死亡例がないことがわかっ た. 3 つまり F/F ratio が $10 \%$ 未満であれば縮小手術の 対象になり得ることを示している (Figure 2A，2B)。し かしこのような形態学的解析は術後の材料を用いた検討 がほとんどで，術前に縮小症例を的確に見つけることは できない，そこで新たな予後マーカーを求めて解析をは じめたのでその中から一部の結果を示したい，我々は典 型的なタイプ $\mathrm{A}$ と典型的なタイプ $\mathrm{C}$ を用いて，それぞれ から組織マイクロダイセクション法を用いて腫瘍細胞の みを抽出し，これから発現遺伝子ライブラリーをつくり 

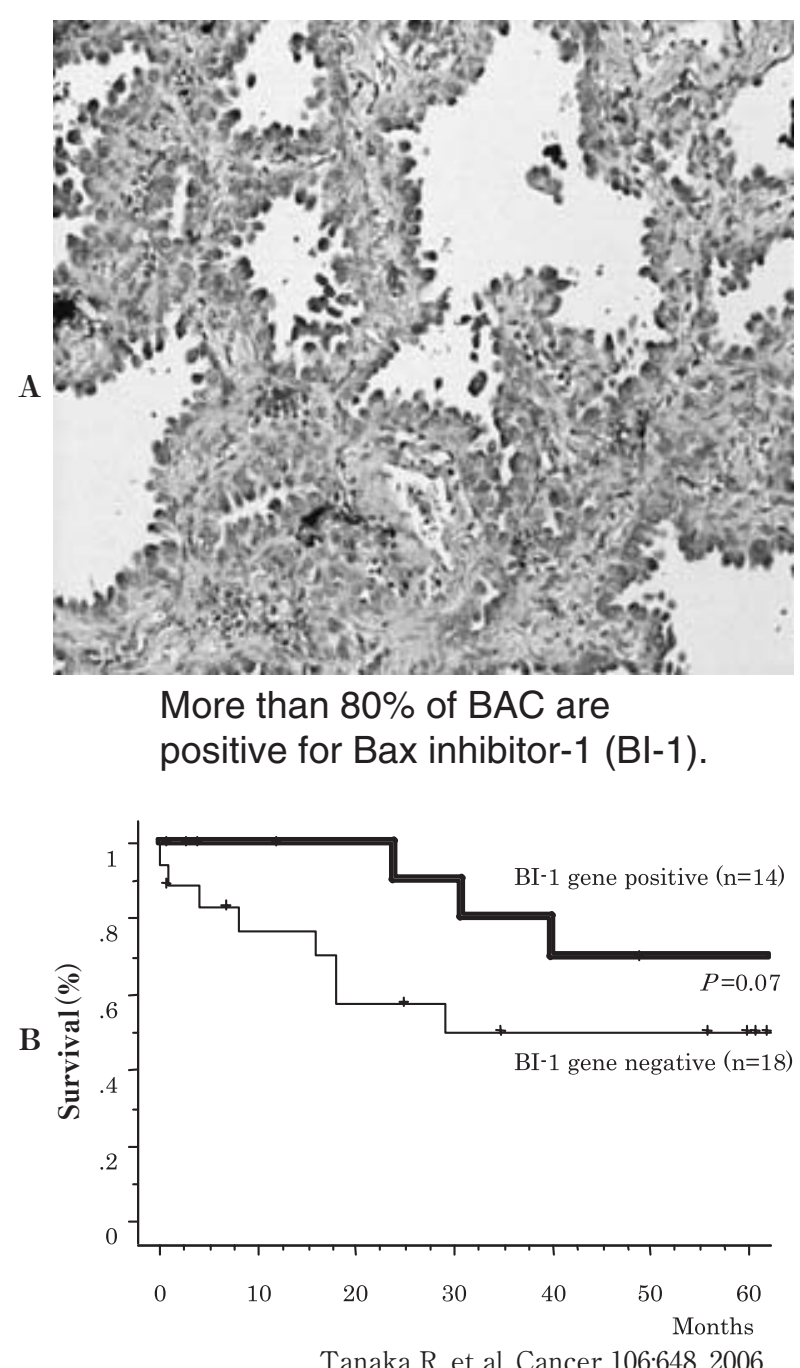

Figure 3.

Table 3. Proposed Modification of the WHO Classification Based on CT Findings and Prognosis

\begin{tabular}{lcc}
\hline \multicolumn{1}{c}{ Histological diagnosis } & CT findings & \\
\hline $\begin{array}{l}\text { Preinvasive lesion } \\
\text { AAH/BAC }\end{array}$ & pure GGO & non-solid \\
\hline Adenocarcinoma & & \\
Mixed adenocarcinoma & & \\
$\quad$ with BAC & mixed GGO & part-solid \\
$\quad$ without BAC & non-GGO & solid \\
Acinar & non-GGO & solid \\
Papillary & non-GGO & solid \\
Solid adenocarcinoma with mucin & non-GGO & solid \\
\hline
\end{tabular}

タイプ $\mathrm{A}$ とタイプ Cの間で発現する遺伝子間で発現量 の差のある遺伝子を網羅的に探索している.この中で夕 イプ A とタイプCの間で発現量の差が見られるいくつ
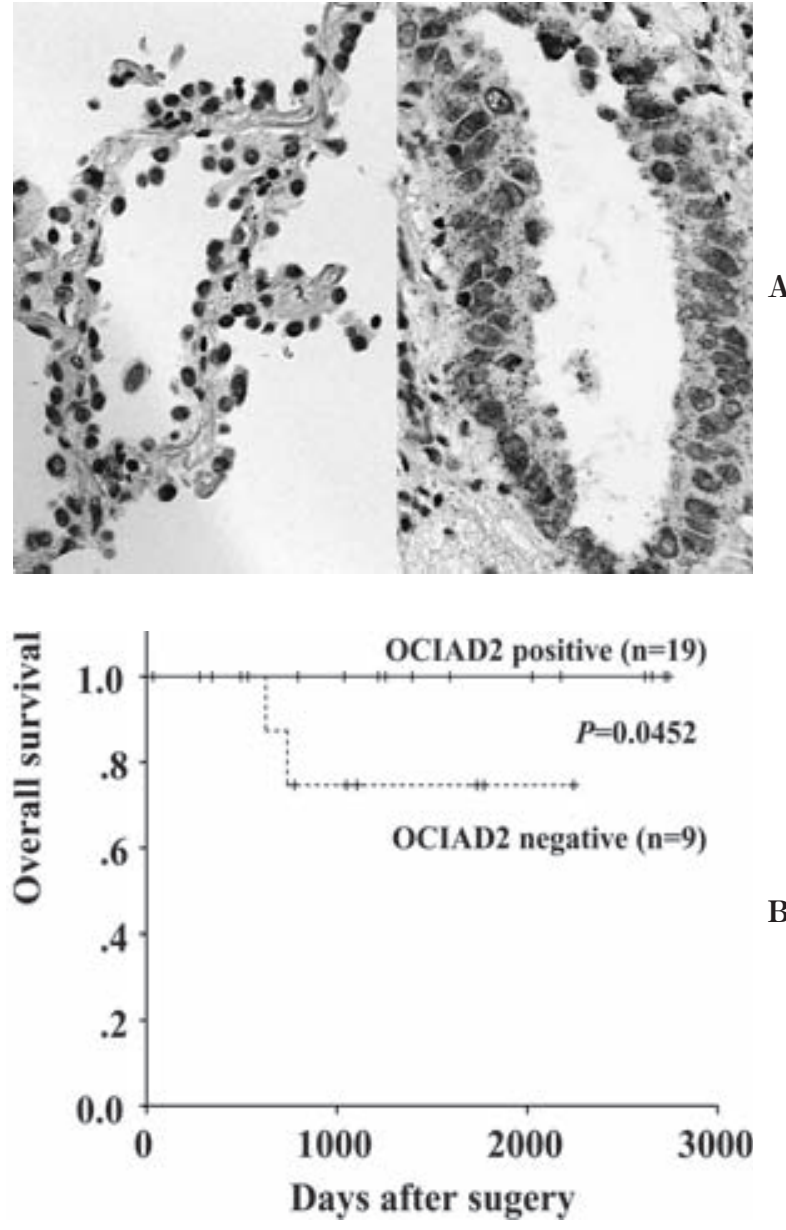

Advanced BAC (type C)

Figure 4.

かの遺伝子が明らかになってきている.タイプ A (BAC) で発現が立進している遺伝子の 1 つにBax inhibitor-1 (BI-1)がある. BI-1 は Bax を介するアポトーシスシグナ ル伝達系の中に位置する蛋白で Bax の機能を阻害する 因子である. BAC 以外の管状腺癌や低分化腺癌での発現 は見られない. 従って BI-1 発現例の予後は非発現例の予 後より有意に良い（Figure 3A，3B）. 4 またタイプCで 発現の立進していた遺伝子の 1 つに ovarian carcinoma immuno-reactive antigen domain 2 (OCIAD2) という遺 伝子がある. この遺伝子はタイプ A に比べてタイプ C に高発現していた遺伝子の 1 つであるが, その発現をin situ hybridization 法で解析すると, 意外なことに OCIAD2 発現症例は非発現症例より予後が良いことが わかった.この結果は一見矛盾しているように思われる が, 我々は OCIAD2 は夕イプCになってはじめて発現 してくる遺伝子で, OCIAD2 発現例は非発現例に比べて 予後が良いのであろうと考えている，実際タイプCにつ 
いてその発現と予後の関係を見てみると OCIAD2 発現 例には癌死例がないことがわかる (Figure 4A，4B). ${ }^{5}$ このような研究はまだ始まったばかりであるが,ささらな る解析で血清マーカーとして用いることができるよう な, あるいはゲノム解析も含めて考えれば生検診断時に 予後予測が可能になるようなマーカー探索が望まれる.

\section{おわりに}

以上小型腺癌の発生要因と生物学についてのべてきた が現行の WHO 分類は肺腺癌の生物学を基盤にした分類 とはいえないことがわかる．おそらく $\mathrm{BAC}$ は非浸潤性 病変に含まれるべきであろうし, 肺腺癌自体の分類も BAC を含む腫瘍なのか含まない腫瘍なのか, また含む場 合は BACの割合がどの程度あるのかが患者の予後を決 める際に重要な情報で, このような基盤のもとに分類が なされていくべきと考えられる (Table 3). 将来的により 良い予後マーカーが明らかになればこれを用いた分類も 検討されるべきであろう.

\section{REFERENCES}

1. Colby TV, Noguchi M, Henschke C, Vazquez MF, Geiniger K, Yokose T, et al. Adenocarcinoma. In: Travis WD, Brambilla E, Muller-Hermelink HK, Harris CC, eds. Pathology and Genetics, Tumours of the Lung, Pleura, Thymus and Heart. Lyon: IARC Press; 2004:35-44.

2. Noguchi M, Morikawa A, Kawasaki M, Matsuno Y, Yamada T, Hirohashi S, et al. Small adenocarcioma of the lung. Histologic characteristics and prognosis. Cancer. 1995;75:2844-2852.

3. Minami Y, Matsuno Y, Iijima T, Morishita Y, Onizuka M, Sakakibara Y, et al. Prognostication of small-sized primary pulmonary adenocarcinomas by histopathological and karyometric analysis. Lung Cancer. 2005;48:339-348.

4. Tanaka R, Ishiyama T, Uchihara T, Inadome Y, Iijima T, Morishita Y, et al. Expression of the Bax inhibitor-1 gene in pulmonary adenocarcinoma. Cancer. 2006;106:648-653.

5. Ishiyama $T$, Kano $J$, Anami $Y$, Onuki $T$, Iijima $T$, Morisita $\mathrm{Y}$, et al. OCIA domain containing 2 is highly expressed in adenocarcinoma mixed subtype with bronchioloalveolar carcinoma component and is associated with better prognosis. Cancer Sci. 2007;98:50-57. 